\title{
Endülüs'te Toplumsal Kutuplaşmanın Sebepleri ve Kültürel Sonuçları
}

Nizamettin PARLAK*

\section{Reasons of Social Polarization in al-Andalus and It's Cultural Consequences}

Citation/C: Parlak, Nizamettin, (2015). Reasons of Social Polarization in alAndalus and It's Cultural Consequences, Milel ve Nihal, 12 (1), 81-106.

Abstract: Different periods in the history of Islam, Muslims had difficulties with a variety of reasons between each other. The problem of polarization and serialized between Muslims were seen in Andalus too. But the destruction, which occurred in this region, was not possible to compensate. Especially the results of cultural destruction were not limited with Andalus, in some way, it influenced the whole Islamic world as well. For this reason, damage of polarization should be well understood and these problems should not be repeated by using the basic resources of Islam and understanding the life of the Prophet Muhammad. Especially, when run in pursuit by establishing some lower belongings such as sect, tarikah and congregation and etc., in the way of reaching a lofty aim, there should not be allowed failures and damage in the basic belongings such as Quran and Prophet.

Key Words: Andalucia, polarization, culture, destruction of books.

Atıf/@: Parlak, Nizamettin, (2015). Endülüs'te Toplumsal Kutuplaşmanın Sebepleri ve Kültürel Sonuçları, Milel ve Nihal, 12 (1), 81-106.

Öz: İslâm tarihinin değişik dönemlerinde Müslümanlar, çeşitli sebeplerle kendi

* Doç. Dr., Erzincan Üniversitesi, İlahiyat Fakültesi, İslâm Tarihi Anabilim Dalı [nizamparlak@yahoo.com] 
aralarında bir takım sorunlar yaşamışlardır. Müslümanlar arasındaki kutuplaşma ve tefrika sorunu Endülüs'te de görülmüş, ancak bu coğrafyada yaşanan yıkımın telafisi mümkün olamamıştır. Özellikle kültürel tahribatın sonuçları Endülüs'le sınırlı kalmamış, bir şekilde bütün İslâm dünyasını da etkilemiştir. Bu yüzden kutuplaşmanın tahrifatı iyi kavranmalı, İslâm'ın temel kaynaklarından ve $\mathrm{Hz}$. Peygamber'in hayatından beslenerek bu sorunlar tekrarlanmamalıdır. Özellikle de mezhep, tarikat, cemaat vb. alt aidiyetler indas edilerek ulvî gayeler peşinde koşulurken Kur'an, Peygamber gibi temel aidiyetlerde kırılmalara ve tahribata yol açılmamalıdır.

Anahtar Kelimeler: Endülüs, kutuplaşma, kültür, kitap, miras.

\section{Giriş}

Endülüs'te Müslümanların kutuplaşmalarının siyasal, sosyal, kültürel ve ekonomik bir takım sonuçları olmuştur. Bu çalışmada konu sadece kültürel açıdan ele alınacaktır. Kutuplaşma; birbirine zıt düşme, birbirine karşıt gruplara ayrılma anlamlarına gelmektedir. ${ }^{1}$ Aslında insanın, kendinden olana karşı daha duyarlı ve himayeci olması normal bir davranış biçimidir. Çünkü bu himayeci ve muhafazakâr eğilim, insanoğlunun sahip olduğu değerleri, kendinden sonrakilere aktarma imkânı sunar. Ancak bu özellik bir takım değerlerle dengelenmezse ayrışma ve kutuplaşma kaçınılmaz olur. ${ }^{2}$ Kutuplaşma bir şekilde zihinlerde yer etmeye başlayınca devamında "ötekileştirmeyi ve çatışmayı", ardından da "ötekini tasfiyeyi" gündeme getirir. Dolayısıyla burada kastedilen, normal bir takım gruplaşmalar ya da toplu faaliyetler değildir. Aksine birbirine zarar vermeyi hedef edinen kutuplaşmalar kastedilmektedir.

Bir toplumda görüş farklılıkları, insanları birbirine kötülük etmeye, birbirine düşmanlık beslemeye, onların birbiriyle temasını engelleyecek parçalara ayırmaya başladığında masumiyetini yitirmiş, tehlike arz etmeye başlamış demektir. Bu anlamdaki kutuplaşmayı "bazı sebeplerden dolayı insanların birbirlerini farklı görmesi,

1 Bkz: Türkçe Sözlük, Türk Dil Kurumu Yay., Ankara, 1983, 769; Saniye Adıüzzel, 21. Yüzyılda Yeni Bir Paradigma: Kentsel Kutuplaşma ve Mersin Örneği, Kahramanmaraş Sütçü İmam Üniversitesi, Sosyal Bilimler Enstitüsü, (Basılmamış Yüksek Lisans Tezi), Kahramanmaraş, 2008, s. 3. İnsanların birbirleriyle çatışmalarını ifade eden" kutuplaşma", "tefrika", "ayrımcıllk" gibi kelimelerin anlamlarının yakın olması sebebiyle mezkur ifadeler, bu çalışma boyunca birbirinin yerine ve aynı anlamı ifade etmek için kullanılacaktır.

2 Vahap Özpolat, Demokratik Vatandaşlık Birlikte Yaşama Kültürü, Hegem Yayınları, Ankara, 2009, s. 182. 
bunun sonucunda da kendisinden ayrı gördüklerine kötülük etmesi" şeklinde tanımlamak mümkündür.

Kur'an-1 Kerim'in ve diğer Kutsal kitapların haber verdiğine göre yeryüzündeki ilk kutuplaşma, ilk insan Hz. Âdem'in çocukları arasında yaşanmış ve sonuçta biri, diğerini ortadan kaldırmıştır. ${ }^{3}$ Aslında dünyadaki bu ilk kutuplaşma, metafizik boyutta yaşanan ve İblis tarafından ilk defa icra edilen ayrımcllığın bir uzantısıydı. ${ }^{4}$ Zira İblis, Allah'ın Hz. Âdem'le ilgili emrine muhatap olunca aklıyla Âdem'i algıladı, onun ayrımına vardı, kendinden farklı gördü, kaçındı, kibirlendi, onu yok saydı. Dolayısıyla Âdem'le iletişimi reddetti, onu dışladı, artık aynı düzeyde bir İblis bir de Âdem vardı. Âdem'i dışladığı için İblis'in onu küçümsemesi ve değersizleştirmesi gerekiyordu. Bu yüzden akıl yürüterek, gururlanarak ve böbürlenerek kendisinin ondan daha üstün olduğunu iddia etti, ceza almasına rağmen yanlışını kabul etmedi ve hata yapmaya devam etti. ${ }^{5}$

Bazı araştırmacılar, kutuplaşmanın tarihini, ilkel diye niteledikleri toplumların bir özelliği olarak sunmaktadırlar. ${ }^{6}$ Hâlbuki en vahşi ayrımcılık uygulamaları, uygar diye vasıflanan çağlarda ve uygar insanlar tarafından gerçekleştirilmiştir. İnsanlık tarihinin evreleri nasıl isimlendirilirse isimlendirilsin göze çarpan ortak bir nokta vardır o da, yeryüzünde kutuplaşmanın, ilk insanla birlikte var olageldiğidir. Dolayısıyla öncelikle bu helak edici davranış biçiminin, bireylerin davranışlarında ve toplumsal yaşamda nasıl tezahür ettiğinin tespiti yapılmalıdır.

\section{Kutuplaşmanın Tezahürleri}

Bazen toplumlarda bir fert ya da grup, farklı görüldüğü için dışlanır ve bir alana sıkıştırılarak ayrıştırılır. Dışlanan unsurlar bir bütünün tamamlayıcı parçası olmaktan çıkıp gereksiz unsurlarmış gibi algı-

el-Maide, 5/27-31; Kitab-1 Mukaddes, 4. Bölüm Tekvin: Kayin ile Habil 4/4-10.

Allah, Hz. Âdem'i yaratınca meleklerden ve İblis'ten ona secde etmelerini istemiş, melekler emrin gereğini yaparken İblis aklı yürüterek, yaratıldığı madde itibariyle kendisinin Âdem'den üstün olduğunu öne sürüp isyan etmiştir. el-İsrâ, 17/61; Sâd, 38/75-76; el-Hicr, 15/30- 31.

5 Sâd, 38/82-83.

6 Erkan Tüzün, "Nietzsche'de ve Heiddegger'de Ayrımcllı̆ı̆ Onaylanması", Ayrumcilık, 29, Felsefelogos Yay., İstanbul, Nisan 2006/I, 107-120; Zerrin Kurtoğlu, "Dünyada Özcü Olmayan Tarzlarda Katılma İmkânı", Ayrımcıllk, 29, Felsefelogos Yay., İstanbul, Nisan 2006/I, 89-94. 
lanır. Ardından dışlanan bu insanlar geleneklerini, dillerini ve kültürel özelliklerini yitirmeye başlar ve asimile olurlar. İnsanlar, dil, din, ırk, renk ve cinsiyet bakımından birbirinden ayrıştırılıp dışlanmaya başlandığında nerede durulacağı belli olmaz.

İberya Yarımadası, Müslümanlar tarafından fethedilmeye başladığında (m. 711) bir iskân politikası çerçevesinde Araplar ve Berberîler bu coğrafyaya kabile yapılarına göre yerleştirilmişlerdi. Müslümanların yerli halk içinde erimesini engellemek için yapılan bu uygulama, başlangiçta maksada hizmet etmişse de daha sonra sorun oluşturmuş, toplumun kaynaşmasını engellediği gibi kutuplaşmaların ve iç savaşların sebeplerinden biri hâline gelmiştir. Nitekim ilerleyen yıllarda Müslümanlar arasında Arap/Berberî, Beledli/Şamlı, Kayslı/Yemenli savaşları yaşanmıştır. ${ }^{7}$

Bu sorunlar ancak merkezî yönetimin, dirâyetli yöneticilerin elinde güçlendiği zamanlarda problem olmaktan çıkmıştır. Nitekim alınan tedbirler, III. Abdurrahman (822-852) döneminde sonuç vermeye başlamış ve toplum Endülüslülük şuuru ekseninde kenetlenme sürecine girmiştir. Ancak ne gariptir ki bu durum daha sonra Endülüs'ü ilhak eden Murâbitlar (1097-1147) ve Muvahhidler döneminde (1146-1248) bu yeni yöneticilere karşı tekrar bir kutuplaşmanın fitilini ateşlemiştir. ${ }^{8}$

Kutuplaşmanın tarafları, mücadelelerine devam ederken amaçlarına ulaşmak için müntesiplerini ikna etme zorundadırlar. Bunu yaparken bir takım argümanlar kullanırlar. Bu uğurda yaptıklarının meşru olduğuna hem kendileri inanmak hem de yandaşlarını inandırmak durumundadırlar. Dolayısıyla kutuplaşmalar toplumlarda değişik şekillerde tezahür eder, ya da öyle gösterilir. Bu durumlar bazen bireysel menfaat çatışmaları olarak; bazen de din, mezhep, cemaat, tarikat çatışmaları şeklinde tezahür eder.

\subsection{Bireysel Menfaat Çatışmaları (Kişisel Düşmanlık)}

Devlet kademelerinde görev yapanların, eşrafın ya da ilim erbabının arasında zaman zaman kişisel sorunlar yaşanması muhtemeldir.

7 Mehmet Özdemir, Endülüs Müslümanları, I, Türkiye Diyanet Vakfı, Ankara, 1994, s. 44-54. Benî Ahmer döneminde yaşananlar için bkz. Abdülaziz Atîk, el-Edebü'l Arabî fi'l-Endelüs, Beyrut 1976, 120; Nizamettin Parlak, Endülüs'ün Çöküşü: Ben̂ิ Ahmer'de Darbeler ve İsyanlar, Hikmetevi Yayınları, İstanbul, 2014.

8 Mehmet Özdemir, Endülüs Müslümanları Kültür ve Medeniyet, Türkiye Diyanet Vakfı, Ankara, 2013, s. 18-19, 110. 
Benzer durumlar Endülüs'te de yaşanmıştır. Bu tür mücadeleler aslında kişisel çıkar hesapları üzerine kurulmuş olmasına rağmen, etkili sonuç alabilmek ve muhalifleri tasfiye etmek için şahıslar, faaliyetlerini, devletin âli menfaatlerine ve dinî hassasiyetlere dayalı olarak yürüttükleri izlenimi vermekten çekinmemişlerdir.

Kendi zamanına kadar Endülüs'ün yetiştirdiği en güçlü fikir adamı olarak kabul edilen İbn Bâcce (532/1138), böyle kişisel bir hıncın sonucunda dinsizlikle itham edilerek hapse atılmış, ortadan kaldırılması gereken bir zındık olarak nitelenmiştir. Özellikle Feth b. Hâkân, İbn Sîd el-Batalyevsî ve Ebu'l-Alâ İbn Zühr gibi önemli zevat, İbn Bâcce'nin muhalifleri arasında yer almış, bilhassa İbn Zühr, İbn Bâcce ile geçinemediğini ve onun yok edilmesi gereken bir zındik olduğunu dillendirmekten çekinmemiştir. Karşıtlarınca zehirlenerek öldürüldüğü iddiaları tartışmalı görülmekle birlikte ölümünde saraydaki ilim adamlarının, kâtiplerin ve başka bazı kişilerin parmağ 1 olduğu ifade edilmiştir. ${ }^{9}$

Bu konuda diğer bir örnek de kadılık ve Kurtuba Ulu Camii'nde imamlık yapmış saygın bir ilim adamı olan İbn Zekvân'ın (ö. 413/1022) başına gelenlerdir. Dönemin vezirlerinden İsa b. Said'in, aklı ermeyen bir kişinin arazisini hileli bir satışla ele geçirmesi üzerine İbn Zekvân bu işlemi hukuken geçersiz saymış, bu yüzden vezir, kendisine düşman olmuş ve aleyhinde yürüttüğü karalamalar sonucu onu kadılkudatlık görevinden aldırmıştır. İbn Zekvân, vezirin ölümünden sonra eski itibarını kazanabilmişse de bir süre sonra yeniden gözden düşmüş, önce Meriye'ye, sonra da Cezayir'e sürgün edilmiştir. ${ }^{10}$

9 Yaşar Aydınlı, “İbn Bâcce”, DİA, c. 19, İstanbul, 1999, s. 348-353; Özdemir, Endülüs Müslümanları, (2013), s. 215-217.

10 Bkz. Ebü'l-Hasan en-Nübâhî, Târihü Kudâti'l-Endelus, (el-Markabetu'l-ulyâ, tah. Lecnetü İhyâit-Türâsi'l-Arabi), Beyrut 1403/1983, s. 84-87; Ebu'l-Abbas Ahmed b. Abdullah b. Herseme b. Zekvân, Dabbi, İbn Zekvân için "Kadı'l-Cema'a" unvanını kullanmıştır. Bkz. Dabbî, Ahmed b. Yahya b. Ahmed el-Endelüsî, (ö. 599/1202), Buğyetü'l-mültemis fì târîhi ricâli ehli'l-Endelüs, Dârül-Kitâbi'l-Arabî, Kahire, 1967, 186; Süha Abbûd Accâr, “íbn Zekvân”, DİA, c. 20, İstanbul, 1999, s. 460-461. 
Meriye' de doğmuş olan meşhur sûfí İbnü'l-Arif (ö. 536/1141) de sırf şöhretinden dolayı şehrin kadısı İbnü'l-Esved'in girişimleri sonucu takibe uğramış ve bizzat kadının girişimleriyle zehirlenerek öldürülmüştür. ${ }^{11}$

İslâm dünyasının diğer bölgelerinde olduğu gibi Endülüs'te de karşı kutupta yer alanların imhasını temin etmek amacıyla standart bir takım gerekçeler üretilmiş ve muhalifler, bu suçları işlemiş olmakla itham edilmişlerdir. Bu gerekçelerin bazıları şunlardır: Şer'i şerîfe müğayir uygulamalar içinde olmak, özel yaşantıda ifrata ve israfa kaçmak, bidatçılık, filozofların görüşlerine uymak, yargıya müdahale etmek, Sultana ihanet etmek. ${ }^{12}$ Görüldüğü üzere insanların suçlanması için kullanılan kalıplar, günümüz için de geçerliliğini korumaktadır. Hem bireylere hem topluma hem de devlete zarar verecek boyuta ulaşabilen bu tür faaliyetler, bazen de daha geniş çerçevede mezhep kutuplaşmaları şeklinde tezahür etmiştir.

\subsection{Mezhebî Farklılıklara Dayalı Çatışmalar}

M. 656 yılında Hz. Osman'ın katledilmesiyle başlayıp Cemel (m.656), Siffîn (m.657), Nehrevan (m.657) ve Kerbela (m.680) ile devam eden olaylar, Müslümanlar arasında kutuplaşmayı derinleştirdi ve birçok mezhebin ortaya çıkmasına sebep oldu. Haricîlik, Şiîlik gibi büyük ölçüde siyasî sebeplerle ortaya çıkan ekoller, bir süre sonra dinî kisveye bürünerek toplumsal tahribata devam etti, daha sonra bunlara itikadî mahiyette yenileri eklendi. ${ }^{13}$

Başlangıçta bu kadar çatışmacı görünmeseler de fikıh mezheplerinin mensupları arasındaki mücadeleler Endülüs'e de taşındı. Şöyle ki fethin akabinde yeni topraklara yerleşenlerin çoğu Suriye asıllı Araplardı. O dönemde Suriye civarında İmam Evzâî'nin görüşleri hâkim olduğundan dolayı Endülüs'te de Valiler Dönemi (714-756) boyunca onun fikirleri genel kabul gördü. Ancak daha sonraları Doğu İslâm dünyasına ilim yolculukları yapan Endülüslü öğrenciler, geri döndüklerinde Malikî mezhebini ülkelerinde yayd1lar. Özellikle, I. Hişam'ın (788-796) onlara sahip çıkması, işin rengini

11 Dabbi, Buğye, 83; Nihat Azamat, “İbnü'l-Arif”, DİA, c. 20, İstanbul, s. 522-523.

12 Bir örnek olarak Benî Ahmer' in ünlü devlet adamı ve tarihçisi Lisânüddîn İbnü'lHatîb'in muhalifleriyle mücadelesi için bkz. Nizamettin Parlak, Lisânüddîn İbnü'lHatîb'in Siyasî Kişiliği ve Tarihçiliği, Türk Tarih Kurumu, Ankara, 2012, s. 58-69.

13 Özdemir, Endülüs Müslümanları, (2013), s. 193. 
değiştirdi ve zamanla ortaya çıkan bir takım gelişmeler Emevî-Abbasî mücadelesi gibi siyasî mahiyete büründü. Bu yüzden İmam Malik'in, Abbasîlere karşı Endülüs Emevîlerini desteklediği ve onların Mekke ve Medine'ye hâkim olmalarını arzuladığı rivayet edilir. ${ }^{14}$

Endülüslü idareciler, ülkenin bütünlüğü için hem siyasî hem de dinî birliğin zarurî olduğuna, özellikle de dinî birliğin, Malikîlik etrafında gerçekleşebileceği kanaatine sahiplerdi. Bu sebeple Malikîlik, Endülüs'ün hâkim mezhebi oldu, yıkılışa kadar da böyle devam etti. Bilhassa Murabitlar döneminde (1091-1147) bu mezhebin mensupları sadece yargıda değil, yönetimde de söz sahibi olmaya başladılar. Dolayısıyla Endülüs'te yayılma istidadı gösteren Zâhirîlik ve Şafî̂lik gibi diğer mezheplere hayat hakkı tanınmadı. Zâhirîliğin temsilcileri "sapıklık" ile itham edildi. ${ }^{15} \mathrm{Bu}$ tür ithamlar farklı kesimler tarafından muhaliflere karşı dillendirilmeye başladı ve sapıklıklarından dolayı katledilmeleri gerektiğine dair fetvalar verecek boyutlara ulaştı. ${ }^{16}$

\section{Kutuplaşmanın Sebepleri}

Kutuplaşma şeklinde nitelenebilecek ayrışmaların çeşitli sebepleri vardır. Başka bir ifadeyle bu durum, doğal bir seyir içinde ortaya çıkması mümkün, alelâde davranış biçimleri olarak değerlendirilemez. Öyleyse bu sebeplerin irdelenmesi ve ortaya konulması, kutuplaşmanın getireceği zararların önüne geçilebilmesi açısından önem arz etmektedir.

Kutuplaşmaların bir kısmının dış etkenlerden, bir kısmının da insanın yapısından kaynaklandığı düşünülmelidir. İnsanların birbirlerine kötülük edecek derecede kutuplaşabilmesi için büyük çabalara, sistematik propagandalara, organize diş müdahalelere çoğunlukla ihtiyaç kalmaz. Çünkü kendi hâline bırakılmış insan fıtratı, bu sorunu üretme potansiyeline sahiptir. Bu yüzden şartları oluştuğunda, ayrımcılık sorunu rahatlıkla ortaya çıkmaktadır. Nitekim felsefeyle uğraşanlar, kutuplaşmayı/tefrikayı akıla dayandırmaktadırlar. Onlara göre; Akıl, yapısal olarak dişlamayla bağlantılıdır. Dolayısıyla o, içine giremediği bir imparatorluğun

\footnotetext{
14 Özdemir, Endülüs Müslümanları, (2013), s. 177-178.

15 Bkz. Mehmet Özdemir, "IX. Yüzyıl Endülüs'ünde Zındıklık Suçlamaları”, Ankara Üniversitesi İlahiyat Fakültesi Dergisi, 38, s. 195-224.

16 Özdemir, Endülüs Müslümanları, (2013), s. 180, 182,186, 189, 213.
} 
varlığını kabul etmemektedir. Ona karşı yönelimi, kuşatmacı, dışlamadır. Akıldan ayrı görülen şey, dışta tutulur ve akıl düzeyinde olmadığından değersiz kabul edilir ve gözden düşürülür. Gözden düşürülmekle yetinilmez, devamında da ona sahip olma, onu kontrol etme ya da onu ortadan kaldırma arzusuna sahip olunur. Çünkü akıl, kendinin farkına varmak için kendinden başka her şeyi dışta tutar ve kendi düzeyinde olmadığı için onları değersiz görür. Bundan dolayı onları gözden düşürür. ${ }^{17}$

Aklın doğal bir faaliyeti olarak değerlendirilen "kutuplaşma" aslında daha genel bir sorun olan adaletsizlik içindeki özel bir durum olarak da değerlendirilmektedir; özü itibariyle kutuplaşma, bizden tanınma talep eden bir başka özneyi reddetmeye dayanır. $\mathrm{Bu}$ yüzden böyle bir eylem, belli bir etik bakışın ya da etikten yoksun bir bakışın ve tutumun sonucudur. Ne tür bir kutuplaşma söz konusu olursa olsun ayrımcılık her zaman bir sonuçtur. Kutuplaşmanın iki ucunda da yer alan herkes, bir değerlendirme hatası yapmakta ve yanlış bir eylem gerçekleştirmektedir. Çünkü tefrikaya düşen kişi, "şey" in değerini saptama yerine kendi kafasındaki değer yargısını karşısındaki kişiye ya da eyleme uygulamaktadır.

Tefrika, kişilere hak ettikleri şeyleri vermemektir. ${ }^{18}$ Bundan dolayı tefrika bir adaletsizlik eylemidir. Zira İslam hukukunda adalet; "bir şeyi yerli yerine koymak," adaletsizlik ise "bir şeyi yerine koymamak" olarak tanımlanmaktadır. Diğer bir deyişle adalet, "yapılması gereken şeyleri yapmaktır." Adaletin zıddı ise zulümdür. Zulüm de "bir şeyi kendine ait bir yerden çıkarıp başka bir yere koymaktır." Daha açık bir ifadeyle "bir kimsenin meşru hakkına tamamen veya kısmen tecavüzde bulunmaktır." 19

Kutuplaşma yalnızca bireysel ölçekte değil, toplumsal alanda da söz konusu olabilmektedir. Toplumsal çapta yaşanan bu eylem bazen şiddete dönüşebilir. Bu yüzden olsa gerek filozoflar kutup-

17 Alex Demiroviç, “Us ve Dışlanmanın Mantığı”, (çev.: Metin Toprak), Ayrımcılık, 29, Felsefelogos Yay., İstanbul, Nisan 2006/I, s. 17-24.

18 Wolf, Frieder Otto, "Ayrımcılık", (Çev. Fehmi Ünsalan), Ayrımcılık, 29, Felsefelogos Yay., İstanbul, Nisan 2006/I, 25-29; Harun Tepe, "Etik Bir Sorun Olarak Ayrımcilık", Ayrimcillk, 29, Felsefelogos Yay., İstanbul, Nisan 2006/I, s. 31-35.

19 Ömer Nasuhi Bilmen, Hukukı İslâmiyye ve Islahatı Fıkhiyye Kamusu, I-VIII, Bilmen Yayınevi, İstanbul, ts. VIII, s. 206-207. 
laşmayı bencilliğin toplumsallaşmış biçimi olarak, bencilliği de insanın doğal şartlardan getirdiği ve insanlaştıkça aşmaya çalıştığı bir durum olarak değerlendirmektedirler. ${ }^{20}$ Özellikle çağdaş yaşamın üretim ve tüketim şartlarının, insanı kendi dünyasında tek başına bıraktığını, dolayısıyla gündelik bilincin sınırlı şartlarında yaşamaya kendilerini mahkûm etmiş olanların "kutuplaşma" denilen toplumsal bencilliğe her zaman düşebilecekleri değerlendirilmektedir. ${ }^{21}$

Hâl böyle olunca kutuplaşma/tefrika, aklın algılama ve davranış geliştirme eyleminden kaynaklanan bir adalet sorunu olmanın yanı sıra etik bir sorun, bir değerlendirme ve insan hakları ihlali sorunu olarak da karşımıza çıkmakta, ${ }^{22}$ bunda da çeşitli sebepler rol oynamaktadır. Bu sebeplerin bir kısmı; üzerinde yaşanılan coğrafyanın, bir kısmı bireylerin davranışlarının, bir kısmı da toplumsal reflekslerin ve uluslararası konjonktürün etkisiyle ortaya çıkmaktadır. Bütün bunlara ek olarak içinde yaşanılan çağın/devrin karakteristik özelliklerinin de farklı coğrafyalarda da olsa toplumlarda benzer davranış biçimlerinin tezahüründe rol oynayabileceği göz ardı edilmemelidir. Bu genel değerlendirmenin ardından Endülüs'te Müslümanlar arasında yaşanan kutuplaşmada etkili olduğunu düşündüğümüz önemli sebeplerden bazılarını başlıklar hâlinde şöylece sıralamak mümkündür.

\subsection{Hedef Yoksunluğu, Savaşlarda Yaşanan Başarısızlıklar}

Endülüs'ün fethi sırasında Musa b. Nusayr ve Tarık b. Ziyad arasinda yaşanan ihtilaf gibi bazı olumsuzluklar, hedefin büyüklüğü ve elde edilen başarılı sonuçlar karşısında fetihleri olumsuz şekilde etkileyecek boyutlara ulaşmamıştı. İberya Yarımadası'ndan sonra Müslüman ordularının önüne Avrupa'nın fethi gibi oldukça heyecan verici yeni bir hedef konulmuştu. Ancak Puvatya Savaşı'nda (m. 732) alınan yenilgi, süreçte ciddi bir kırılma yaşanmasına sebep olmuş, Endülüs'e geri çekilen fatihler birbiriyle çatışmaya başlamıştı. ${ }^{23}$ Aslında buna belki de hedef sapması demek gerekir ki bir sonraki başlık bu maddenin mütemmimi mahiyetindedir.

\footnotetext{
20 Ata Devrim, “Türcülüğün Felsefî Ve Psikanalist Dayanaklari” Ayrrmcıllk, 29, Felsefelogos Yay., İstanbul, Nisan 2006/I, 161-175.

21 Devrim, s. 161-175; Afşar Timuçin, "Ayrımcilık", Ayrımcllık, 29, Felsefelogos Yay., İstanbul, Nisan 2006/I, 37-38.

22 Wolf, "Ayrimclik", s. 31-35.

23 Özdemir, Endülüs Müslümanlarl, (2013), s. 139.
} 


\subsection{Kur'an'dan-Sünnetten ve Ulvî gayelerden Uzaklaşma}

Endülüs'ün fethi sırasında "yeryüzünde Allah'ın isminin duyulmadığı bir yer kalmasın" gibi ulvî bir hedef etrafında birleşmiş olan insanlar, zamanla yaşanan kutuplaşmanın sonucunda tepeden itibaren çözülmeye başlamış, idarecilerle halk ayrışmış, toplum bölünmüş, insanlar; dar alan savunması diye nitelenebilecek kişisel çıkarlarını ve kazanımlarını muhafaza etme derdine düşmüşlerdir. Nitekim III. Abdurrahman döneminde refah düzeyi çok yükselmiş, bu yüzden halkın büyük bir kısmı olaylara maddî açıdan bakmaya başlamıştı. ${ }^{24}$ Hâlbuki İslâm dini Müslümanların genel menfaatini ve ittifakını kişi, grup ve mezhep çıkarlarının üstünde tutmuş, ulvî gayeler etrafında kenetlenmeyi gerekli görmüştür. ${ }^{25}$

Mücadele kriterleri genel-geçer kuralların dışına taşınıp bencillik boyutunda yürütüldügünde, dünyevîleşme kaçınılmaz olur. Unutulmamalıdır ki daha büyük bir hedefe birlik içinde yol alınırken kişisel beklentiler de zaten bir şekilde tahakkuk eder. Ancak kutuplaşmanın sonucunda hırsla ve parçalanmış olarak yapılacak mücadele, fayda vermeyeceği gibi içinde bulunulan devletin, toplumun helakine yol açacar ve sürdürülmesi arzu edilen kişisel çıkar ve kazanımlar da diğerleriyle birlikte yok olup gider. Bir örnek olarak Benî Ahmer Devleti'nin XIV. yüzyıldaki devlet ricali, ilim ehli ve yargı mensuplarının kişisel çatışmalarına bakmak yeterli olacaktir. ${ }^{26}$

\subsection{Siyasî İhtiraslar ve Çıkar Çatışmaları}

Endülüs Emevî, Devleti'nin (756-1031) son yılları, Mülûkü't-Tavâif (1031-1099) dönemleri ve Benî Ahmer Devleti'nin (1238-1492) siyasî tarihi, özellikle de son on yılı bu tür yıkıcı ihtirasların ve kanlı çatışmaların yaşandığı zaman dilimleri olmuştur. Endülüs Emevîleri'nin son yirmi yıll, yönetimi ele geçirmek için kendi aralarında yaşanan,

24 Parlak, Endülüs'ün Çöküşü s. 127; Geniş bilgi için bkz. W. Montgomery Watt Cachia, Pierre, Endülüs Tarihi, (C. Esin Adıgüzel, Qiyas Şükürov), Küre Yay., İstanbul, 2011, s. 92.

26 Bkz. Parlak, Lisânüddîn, s. 58-69. 
zaman zaman da Amirîler ${ }^{27}$ ve Hammudîler ${ }^{28}$ gibi güçlü ailelerin olaylara müdahil olmasıyla gittikçe büyüyen çatışmalarla geçmiş ve devletin yıkılmasıyla sonuçlanmıştır. Endülüs Emevilerinin yerini alan Mülûkü't-Tavâif sultanları ise Endülüs'teki Hıristiyan krallıklarla işbirliği yapmak suretiyle kutuplaşmayı doruk noktasına ulaştırmışlardır. Endülüslüleri, Kuzey Afrika'dan gelen Murabıtlar ${ }^{29}$ daha sonra da Muvahhidler ${ }^{30}$ ancak bir çatı altında toplayabilmişlerdir. ${ }^{31}$ Benî Ahmer sultanlarının ihtirasları ise ortalama her yirmi yılda bir saltanat değişikliğine yol açan darbelerin yaşanmasına sebep olmuştur. Üst düzeyde vukû bulan bu kutuplaşma, zamanla diğer idarecileri, ulemayı ve halkı da içine alacak şekilde derinleşip Endülüs'te İslâm hâkimiyetinin kaybedilmesiyle neticelenmiştir. ${ }^{32}$

\subsection{D1ş Güçlerin Tahrik ve Teşvikleri}

Halifelik döneminde (929-1031) Endülüs'ün Kuzeyindeki Hıristiyan krallıklar ve kontluklar, Endülüs Emevî Devleti'ne vergi ödeyen vasal (uydu) devletler konumundaydı. Ancak Müslümanlar arasında yaşanan kutuplaşma vb. sebeplerle devlet yıkılınca Mülûkü’tTavâif denilen küçük şehir devletleri ortaya çıkmış, bu devletler de hayatta kalabilmek için komşuları olan Hıristiyan krallıklarına vergi vermek zorunda kalmışlardır. Endülüs'te Müslümanların yaşadıkları bu gibi fetret dönemlerinde, kuvvet dengesi Hıristiyan krallıklar lehine oluşmuş, bu durumdan istifade eden krallar, Müslümanların

27 1021-1094 yılları arasında Belensiye' de (Valencia) hüküm süren Müslüman hânedan. Abdülkerim Özaydın, "Âmirîler" DİA, c. 3, İstanbul, 1991, s. 72-73. Geniş bilgi için bkz. İbnü'l-Hatîb, A'mâlü'l-a'lâm fî̀men bûyi'a kable'l-ihtilâm min mulûki'lİslâm, (tahk.: Levi Provençal), Beyrut 1956, s. 59-128.

28 Kurtuba, İşbîliye, Mâleka ve Cezîretülhadrâ' da 1016-1058 yılları arasında hüküm süren bir İslâm hânedanı. Mehmet Özdemir, "Hammûdîler", DİA, c. 15, İstanbul, 1997, s. 496-497; Geniş bilgi için bkz. İbnü'l-Hatîb, A'mâlü'l-a'lâm, s. 128-143.

29 1056-1147 yılları arasında Kuzey Afrika'da hüküm süren ve 1090'da Endülüs'ü ilhak ederek altmış yıla yakın orayı idare eden Berberî hânedanı ve devleti. İsmail Yiğit, "Murâbitlar" DIAA, c. 31, İstanbul, 2006, s. 152-155. Geniş bilgi için bkz: İbnü'l-Hatîb, Târihü'l-Mağribi'l-arabî fî asri'l-vesît, Dârü'l-Beyzâ 1964, s. 225-266.

30 Kuzey Afrika'da Murâbıtlar'1 yıkarak 1130-1269 tarihleri arasında hüküm süren ve 1146 'da Endülüs'ü ilhak edip yaklaşık yüz yıl idare eden Berberî hânedan. Mehmet Özdemir, "Muvahhidler" DİA, c. 31, İstanbul, 2006, s. 410-412; Geniş bilgi için bkz: Abdülmelik İbn Sâhibis-Salât, (ö. 594/1198' den sonra), el-Menn bi'limâme (Târîhü bilâdi'l-Mă̆ribi ve'l-Endelüs fî ahdi'l-Muvahhidîn, tahk.: Abdülhâdî et-Tâzâ), Beyrut 1987; İbnü'l-Hatîb, Târihü̈'l-Mağrib, s. 266-271

31 Özdemir, Endülüs Müslümanları, (2013), s. 119, 121.

32 Geniş bilgi için bkz. Parlak, Endülüs'ün Çöküşü, 57-209. 
iç işlerine karışmaya başlamışlar, yaptıkları müdahalelerle onların aralarındaki kutuplaşmayı daha da derinleştirmişlerdir. Bu arada Müslüman devletçiklerin idarecileri de birbirlerine üstünlük sağlama derdine düştüklerinden dolayı Hıristiyanlardan yardım istemek suretiyle onların hedeflerine ulaşmalarına kendi elleriyle imkân sağlamışlardır. ${ }^{33}$

\section{Kutuplaşmanın Kültürel Sonuçları}

Öncelikle şunu belirtmek gerekir ki Endülüs'te Müslümanlar arasında yaşanan ve başını kutuplaşmanın çektiği ayrılıklar, siyasî birliğin kaybolmasına kültürel tahribata ve nihâî olarak da devletin ve toprakların elden çıkmasına kısacası Endülüs'ün ve Endülüslülerin toptan imhasına sebep olmuştur. Çünkü çatışmalar, Müslümanların güç kaybına yol açmış bu durum da toprak kayıplarını intaç etmiştir.

Böylece Endülüs'te kelimenin tam anlamıyla sosyal bir çözülme yaşanmıştır. Gerçekleşen işgaller sonunda insanlar, katliamlara, köleleştirilmelere, tecavüzlere maruz kalmışlardır. Sağ kalıp canını kurtaranlar, sürgün edilmiş ya da kitlesel olarak göçmek zorunda bırakılmışlardır. Bütün bu yaşananlar, insanların birbirleriyle, devletleriyle ve devletin kurumlarıyla olan ilişkilerinde büyük travmalara yol açmış, düzen bozulmuştur. Hâl böyle olunca huzurlu ve düzenli bir ortamda sergilenen davranış biçimleri, savrulmuş insan kitlelerinden beklenemez. Bunun devamında da kişinin kendisine, ailesine, dinine ve devletine karşı görevlerini yerine getirmesindeki ihmaller gündeme gelir. Dinin emir ve yasaklarında yaşanan savsaklama, kişilerin "günahkâr", "ahlaksız" "sapık", "kâfir" diye; devlete karşı sergilenen ihmaller yüzünden de "hain", "asi" şeklinde yaftalanmaları söz konusu olur. Böylece kısır bir döngü içine girilir. Artık toplumda ahlaksız fiillerin, zararlı alışkanlıkların, sahtekârlıkların ve suçların önü alınamaz olur. ${ }^{34} \mathrm{Bu}$, sosyal bir bunalımdır. Toplum bundan sonra o ana kadar biriktirdiklerini savurmaya başlar. Bir toplumda yaşanan sosyal çözülme, beraberinde kültürel çözülmeyi ve yozlaşmayı getirir.

33 Özdemir, Endülüs Müslümanları, (2013), s. 111-112.

34 Toğrul İsmayıl, Azerbaycan'da Üniversite Gençliğinin Sosyo-Kültürel Yapısı, İstanbul Üniversitesi Sosyal Bilimler Enstitüsü, (Basılmamış Yüksek Lisans Tezi), İstanbul, 2010, s. 136-140 


\subsection{Kültürel Çözülme}

Endülüs'te yaşanan sosyal çözülme, kaçınılmaz bir biçimde kültürel faaliyetlere yansımış ve ağır bir tahribata sebep olmuştur. Bu kaos ortamında Endülüs'ün yetiştirdiği güzide insanlar, özellikle de ilim adamları katledilmiş, tekfir edilmiş, hapsedilmiş, baskı altına alınmış ve ülkeyi terk etmeye zorlanmışlardır. Yılların birikimi olan değerli kitaplar yakılıp imha edilmiştir.

\subsection{1. İlim Ehlinin Faaliyetlerinin Engellenmesi}

Kutuplaşmalar sonucu Endülüs'te çok sayıda iç çatışma ve isyan yaşanmıştı. Nitekim Kurtuba'da meydana gelen Rabad Vak'ası"nda $(202 / 818)^{35}$ özellikle ilim erbabı arasından öldürülenler, sürülenler ve hapsedilenler olmuştur. Eğitim-öğretim faaliyetleri, telif-tasnif, sanatsal/mimarî etkinlikler durmuştur. Emniyet ve asayişin sağlanamaması ve ulemanın başka şehirlere göç etmesi sebebiyle Kurtuba Ulu Camii'nde yürütülmekte olan başta Kura'n-1 Kerim eğitimi ve diğer ilimlerin ders halkaları dağılmış, ${ }^{36}$ bu tür çatışma ortamlarında hayatını kaybedenler olmuştur. Nitekim daha sonraki dönemlerde Endülüs'ün yetiştirdiği önemli tarihçilerden İbnü'1-Faradi (403/1013), yine bir kargaşa sonucu Kurtuba'da Berberî isyancılar tarafından öldürülmüştür. ${ }^{37}$

Yukarıda Endülüs'te mezhebe dayalı kutuplaşmadan ana hatlarıyla bahsedilmişti. Burada ise somut örnekleriyle konuyu ele almak gerekecektir; Endülüs'te iki kuşak boyunca önemli ilmî ve hukûkî faaliyetlere imza atan Malikî uleması, ikinci kuşaktan sonra, önceki ilim adamlarının görüşlerini taklit etmeye ve onların yazdıklarını ezberlemeye başlamışlardır. Bu durum ulema arasında ciddi

35 Endülüs'te I. Hakem döneminde (m.796-822) Kurtuba'da bir isyan meydana geldi. Fukaha, Hakem'in yaşam biçimini tenkit ederek halkı isyana teşvik etti (m.805). Ancak ayaklanma bastırıldı, yetmiş iki kişi idam edildi. Fakat 818 yılında daha büyük bir olay yaşandı (202/818). Hareketin liderleri, Tâlût el-Fakîh, Yahya b. Yahya ve Lisânüddin İbnü'l-Hatîb'in dedesi İbnü'l-Vezîr gibi ileri gelen zevattı. I. Hakem, stratejik hamlelerle bu isyanı da bertaraf etti. Özdemir, Endülüs Müslümanları, I, (1994), 73-75. Geniş bilgi için bkz. İbnü'l-Hatîb, A'mâlü'l-a'lâm, s. 15-17.

36 Bkz. Abdurrahman Abdurraûf el-Hancî, "Eserü fitneti Kurtuba ale'l-mürtekezâti'n-nefsiyye ve'l-ahlâkıyye li'bni Hazmi'l-Endelüsiyyi fî kitâbihi Tavku'lHamâme", es-Sicillü'l-ilmîli-nedveti'l-Endelüs, I-V, nşr. Abdullah b. Ali ez-Zeydân ve dğr., I, Riyad: Mektebetü'l-Meliki'l-Abdilazizi'lâmme, 1996, s. 133-157.

37 Thomas B. Irving, “İbnü'l-Faradi”, DİA, c. 21, İstanbul, 2000, s. 39-40. 
bir tahammülsüzlüğe neden olmuş, hatta el-Muvatta şerhi dışında bir eserle uğraşılmasını zararlı görmelerine, Ebû Hanife (ö. 150/767), Şafiî (ö. 204/820), Davud ez-Zahirî (ö. 270/884) gibi ulemanın görüşlerini benimseyenleri "sapık" ilan etmelerine yol açmıştır. Bâkî b. Mahled (ö. 276/889) görüşlerinden dolayı zındıklıkla suçlanmış, Muhammed b. Kasım el-Kurtubî (ö. 278/891) ise Doğu'dan Endülüs'e döndüğünde, çatışmaya yol açacağı düşüncesiyle Mâlikî fukahasının hoşuna gitmeyecek görüşleri yazmaktan çekindiğini itiraf etmiştir. Ebû Bekir et-Turtuşî (ö. 520/1126), hac ibadetini ifa ve ilim tahsil etmek için gittiği Doğu'dan (Irak, Suriye, Mısır), ülkesinde karşılaşacağını tahmin ettiği sert muhalefetten dolayı Endülüs'e dönmek istememiştir. 38 İbrahim b. Mûsâ eş-Şâtıbî (ö. 790/1388) döneminin mâlikî fukahasıyla ve kadılarıyla yaşadığı ihtilaf yüzünden Rafizîlikle, sahabe düşmanlığ1 yapmakla suçlanmış ve muhtemelen savunduğu fikirler yüzünden görevinden alınmıştır. ${ }^{39}$

Endülüs'ün önemli ilim adamlarından biri olan İbn Hazm (ö. 456/1064) hem dönemin Mâlikî ulemasıyla olan görüş ayrılıklarından hem de siyasî çekişmelerden dolayı ciddi sorunlar yaşamış, "sapık" ilan edilmiş, işkenceye ve sürgüne maruz kalmıştır. 40 İbn Meserre (ö. 319/931), Malikî fukahasının baskıları yüzünden faaliyetlerini gizli yürütmek zorunda kalmış, ancak takibattan ve zındıklık suçlamalarından kurtulamamış, gerek hayattayken gerekse ölümünden sonra öğrencileri tövbeye davet edilmiş, İbn Meserreci olarak bilinenlerin çoğu Endülüs'ten kaçmışlardır. ${ }^{41}$ İbn Rüşd (ö. 595/1198) de benzer sebeplerden dolayı inkârcılıkla suçlanmış, gözden düşmüş, sürgüne gönderilmiş ve eserleri yakılmıştır. İbnü'l-Faradî (ö. 403/1013), ${ }^{42}$ İbnü'l-Gurbâlî (ö. 403/1013)43, İbn Şüheyd (ö.

38 Özdemir, Endülüs Müslümanları, (2013), s. 171, 180-181.

39 Ahmed er-Reysûnî - Ali Hakan Çavuşoğlu, "Şâtıbî, İbrahim b. Mûsâ", DİA, c. 38, İstanbul, 2010, s. 373-375; Özdemir, Endülüs Müslümanları, (2013), s. 192.

40 H. Yunus Apaydın, “İbn Hazm”, DIA, c. 20, İstanbul, 1999, s. 39-52; Özdemir, Endülüs Müslümanları, (2013), s. 189.

41 Mustafa Çağrıcl, “İbn Meserre”, DİA, c. 20, İstanbul, 1999, s. 188-193; Özdemir, Endülüs Müslümanlarl, (2013), s. 210-214.

42 Thomas B. Irving, "İbnü'l-Faradî”, DİA, c. 21, İstanbul, 2000, s. 39-40.

43 İbnü'l-Gurbâlî, Endülüs'te isyanların baş gösterdiği bir dönemde âsî Berberîlerin Kurtuba'yı ele geçirmeleri esnasında (19/20 Nisan 1013) öldürüldü. Ömer Mahir Alper, “İbnü'l-Gurbâlî”, DİA, c. 21, İstanbul, 2000, s. 50. 
426/1035), ${ }^{44}$ İbn Sîde (ö. 458/1066), ${ }^{45}$ İbn Zeydûn (ö. 463/1071), ${ }^{46}$ İbn Vehbûn (ö. 483/1090), ${ }^{47}$ Ebû Bekir İbnü'l-Arabî (ö. 543/1148), ${ }^{48}$ İbn Seb'în (ö. 669/1270) kutuplaşma sonucu yaşanan mücadelelerin akabinde hayatını kaybeden ya da Endülüs'ü terk etmek zorunda kalan ilim ehlinden sadece bir kaçıdır. ${ }^{49}$

44 İbn Şüheyd, fikir, tavır ve davranışlarından dolayı Hammûdîler döneminde bir süre hapsedildi, maddi sıkıntılar yaşadı. Bu sorunlar onun dost ve arkadaşlarını kaybetmesine yol açtı. Dabbi, Buğye, s. 193; Mustafa Aydın, "İbn Şüheyd", DIA, c. 20, İstanbul, 1999, s. 382-383.

45 Doğduğu kent olan Mürsiye'yi muhtemelen orada meydana gelen siyasî olaylar yüzünden terk etmek zorunda kalmıştır. Zülfikar Tüccar, "İbn Side", DİA, c. 20, İstanbul, 1999, s. 318-319.

46 Kurtuba'daki ayaklanmalar sırasında (m. 1031) meydana gelen kutuplaşmada taraf olmuş, itibar görmüş sonra hapse düşmüş ardından da hapisten firar ederek İşbiliye'ye kaçmak zorunda kalmıştır. Daha sonra Kurtuba'ya dönüp vezirlik görevi üstlenmiş olmasına rağmen muhtemelen muhaliflerinin iftiraları yüzünden Kurtuba'yı yine terk etmek zorunda kalmıştır. Rahmi Er, "İbn Zeydûn”, DİA, c. 20, İstanbul, 1999, s. 464-466.

47 Rahmi Er, "İbn Vehbûn”, DİA, c. 20, İstanbul, 1999, s. 443.

48 Muhaliflerinin tepkileri yüzünden İşbiliye kadılığı görevinden ayrılmak zorunda kalmıştır. Ahmet Baltac1, “İbnü'l-Arabî”, DİA, c. 20, İstanbul, 1999, s. 488-492.

49 Özellikle İbn Rüşd için bkz. Nübâhî, Târihü Kudâti'l-Endelus, 98-99; Bekir Karlığa, “İbn Rüşd” DİA, c. 20, İstanbul, 1999, s. 257-288; Mehmet Özdemir, “İbn Rüşd'ün Yaşadığı Asırda Endülüs", Diyanet İlmî Dergi, c. 48, sayı: 3, Ankara, 2012, s. 7-30; Ömer Bozkurt "13. Yüzyıl İslam Düşüncesinde İbn Rüşd'e Olan İlgisizliğin Sebep ve Sonuçları Üzerine" Uluslar arası 13. Yüzyılda Felsefe Sempozyumu, Ankara, 16-17 Kasım 2013. (Uluslararası 13. Yüzyılda Felsefe Sempozyumu Bildirileri, ed. M. Demirkol, E. Kala, YBU Yayınları, Ankara, 2014, s. 682-700. 


\subsubsection{Kitapların Yakılıp İmha Edilmesi ${ }^{50}$}

Tarih boyunca kitap ve kütüphane yakma eylemleri var olagelmiştir. ${ }^{51}$ İslâm tarihinde de çeşitli sebeplerle kitapların yakıldığı bir vakıadır. Fakat Endülüs'te bu hadise, sonuçları itibariyle çok farklı boyutlarda yaşanmış, orada Müslümanlar arasında yaşanan kutuplaşmanın sonucunda çok sayıda kitap imha edilmiştir. Kitapların yakılması, bu çalışmanın önemli kültürel unsurlarından birini teşkil etmesi nedeniyle bu husus üzerinde ayrıntılı olarak durulması zarureti vardır.

"Kitap medeniyeti" olarak nitelenen Endülüs'te, yüz binlerce el yazması esere sahip kütüphaneler kuruldu. II. Hakem'in şahsî gayretleriyle dört yüz bin ciltten fazla kitabı olan büyük bir kütüphanesi vardı. Bunun dışında çok sayıda kitabın toplandığı özel kütüphaneler tesis edildi. Kurtuba, Meriye, İşbiliye, Tuleytula, Gırnâta, Sarakusta, Belensiye, Mürsiye, İlbîre, Şâtibe ve Menorka şehirlerinde idareciler ya da şahıslar tarafından kurulmuş büyük kütüphaneler mevcuttu. ${ }^{2}$

50 "Kitapların yakılması" başlığıyla kastedilen şey, her hangi bir sebepten dolayı zararlı görülen kitapların her ne şekilde olursa olsun bir daha okunamayacak şekilde imha edilmesidir. Tarihte kitapları imha etmenin en bariz şekli, 'yakma' olduğundan dolayı başlık bu şekilde seçilmiş, ama bu ifadeyle, bütün imha şekilleri kastedilmiştir. Nitekim Hz. Peygamber' in vefatından sonra Hz. Ebû Bekir, hadisleri derlemek için bir çalışma yapıp içinde beş yüz hadis bulunan bir kitap oluşturmuştu. Ancak Peygamber'e ait olmayan bir sözü ona isnat etmiş olmaktan korktuğu için bu kitabı imha etmiştir. Burada Hz. Ebû Bekir'in imha şekli dikkat çekicidir. $\mathrm{O}$, bu kitabı yakarak ya da yırtıp parçalayarak değil suyla yıkayıp yazılarını silerek ortadan kaldırmıştır. Niçin böyle bir imha şeklinin seçildiği meselesi üzerinde ayrıca durulması gerekir. Muhammed Hamidullah, İslâm'ın Doğuşu, (çev.: Murat Çiftkaya), Beyan Yayınları, İstanbul, 2010, s. 71.

51 Tevrat ve İncillerin yakılması hususunda bkz. Hamidullah, İslâm'ın Doğuşu, s. 17, 19. Moğolların kitap imhaları için bkz., Roger Garaudy, Endülüs'te İslâm, (çev.: Cemal Aydın), Türk Edebiyatı Vakfı Yayınları, İstanbul, 2014, s. 271. Özdemir, Endülüs Müslümanları, (2013), s. 157-160. Doğu'da da Müslümanlar, muhteşem kütüphaneler kurmuştu. Halife Me'mun'un m. 815'de Bağdat'da kurduğu Beytü'l-Hikme'de bir milyon eserin olduğu, 891 yılında Bağdat'da yüzden fazla halk kütüphanesinin bulunduğu, Necef kütüphanesinde kırk bin, Merağa rasathanesinin başındaki Nâsırüddîn Tûsî'nin kütüphanesinde ise dört yüz bin cilt kitabın olduğu rivayet edilir. Garaudy, bundan dört yüz yıl sonra "Bilge" diye meşhur olan Fransa Kralı Beşinci Charles'in kütüphanesindeki kitap sayısının sadece dokuz yüz olduğunu kaydeder. Garaudy, Endülüs'te İslâm, s. 279-280. 
$\mathrm{Bu}$ yüzden çeşitli sebeplerle gerçekleşen kitap yakma eylemlerinde imha edilen kitap sayısının yüz binlerle ifade edilmesi mübalağalı görülmemelidir. Ancak burada meselenin önemli bir ayırımı gözden kaçırılmamalıdır; kitap imhalarının bir kısmı Müslümanlar tarafından yine Müslüman müelliflerin eserlerinin yakılması şeklinde tezahür etmiş, bunun dışında İslâm'a ve Müslümanlara ait te'lifat, Hıristiyanlar tarafından da yakılmıştır.

Endülüs'te bazen kişisel husumetler, bazen siyasî mücadeleler, kimi zaman da dinî kaygılarla, bazı müellifler sakıncalı ilan edilmiş ve eserlerinin okunması, istinsah edilmesi ve hatta elde bulundurulması bile suç kabul edilerek takibata ve cezalandırılmaya sebep teşkil etmiştir. Hâl böyle olunca zararlı görülen kitapların yakılarak imha edilmesi, en sağlıklı yol olarak görülmüştür.

İbn Meserre ve öğrencileri, Mâlikî fukahâsı tarafından tehlikeli görülüp takibata uğramış ve Medînetüzzehrâ'daki saray kütüphanesinde bulunan kitapları ayıklanarak, Mâlikî fakihi ve Kurtuba kâdılcemaâsı İbn Zerb (ö. 381/991) tarafından yakılmıştır (350/961). ${ }^{53}$ Konuyla ilgili olarak XIV. yüzyılda Gırnata'da yaşamış kadılkudat Ebu'l-Hasan en-Nübâhî (ö. 792/1390) şu bilgileri kaydetmiştir: “Kadı İbn Zerb, İbn Meserre'nin yolundan gidenleri tespit edip ortaya çıkarmak ve tövbe etmelerini sağlamak için yoğun çaba harcadı. Müsadere edilip huzuruna getirilen bütün İbn Meserre müntesipleri tövbe ettiler. Daha sonra İbn Zerb, Kurtuba Camii'nin doğu köşesinde oturarak o insanlardan toplanan kitapları, onların ve orada hazır bulunan diğer insanların gözü önünde yaktı." 54

Gazzalî’nin (ö. 505/1111), İbn Rüşd'ün (ö. 595/1198), İbn Hazm'ın (ö. 456/1064), İbnü'l-Hatîb'in (ö. 776/1374) ve başka müelliflerin eserlerinin toplanarak meydanlarda yakılması, konunun

53 Özdemir, Endülüs Müslümanları, (2013), s. 74, 212. Kallek, İbn Zerb'in Kurtuba kâdılcemâalık görevine 367/978 tarihinde getirildiğini ve vefatına kadar bu vazifede kaldığını kaydeder. Cengiz Kallek, "İbn Zerb" DIA, c. 20, İstanbul, 1999, s. 463. Nübâhî de bu bilgiyi verdiği yerde İbn Zerb'in unvanını sadece "kadı" şeklinde zikreder ve kitapların yakılma hadisesinin tarihini de H. 350 (m. 961) olarak verir. Nübâhî, Târihü Kudâti'l-Endelus, 78. Öyleyse İbn Zerb, kitapları yaktırdığı tarihte henüz Kurtuba kâdılcemâalığı görevine getirilmiş değildir. Bu durumda çıarılacak sonuçlardan biri de şu olabilir: Muhtemelen İbn Zerb bu tür faaliyetlerine devam edip itibar kazandığından dolayı kâdılcemâa makamına terfi ettirilmiş olmalıdır.

54 Nübâhî, Târihü Kudâti'l-Endelus, s. 78, 201. 
önemli örneklerini teşkil etmektedir. İbn Hazm, kitaplarını yakanlara bir şiirle cevap vermiştir. O şiirin birkaç mısraı şöyledir:

Yakabilirsiniz onca kâğı̀dı elbette sizler Ama yakılamaz kâğıdın taşıdı̆̆ı düşünceler Hele beynimdekine, hiçbir el, asla değemez. ${ }^{55}$

Benî Ahmer Devleti'nin vezirlerinden, tarihçi Lisânüddîn İbnü'l-Hatîb ile Gırnâta kadılkudatı Ebu'l-Hasan en-Nübâhî (ö. 792/1390) arasında yaşanan siyasî kutuplaşma, altmış civarında eser te'lif etmiş bu büyük müellifin kitaplarının yakılmasına yol açmıştır. Nübâhî, Gırnâta'nın Bâbu'r-Remle meydanında İbnü'l-Hatîb'in akâid ve ahlakla ilgili bazı eserlerini muhtevasından dolayı yaktırmış (H. 773/1371). ${ }^{56}$ İbnü'1-Hatîb bu olayı "kitaplar yakıldı, hasenât yok edildi" şeklinde değerlendirmiştir. ${ }^{57}$

Reconquista $^{58}$ sürecinde Hıristiyanlar, işgal ettikleri Müslüman şehirlerde büyük yıkım gerçekleştirdiler. Müslümanların uğradıkları, katliam, işkence, tecavüz ve talanlar, ilgili kaynaklara, araştırmalara havale edilerek, burada sadece kütüphane ve kitaplar konusunda yaşanan tahribat dikkatlere sunulacaktır.

Endülüs kütüphanelerinin bir kısmı, Hıristiyan işgalinden önceki iç savaşlar sebebiyle yağma, talan ve tahribat yaşadı, kitapların bir bölümü ise Kuzey Afrika'ya taşınd1. ${ }^{59}$ Hıristiyan işgaliyle başlayan süreçte ise tam bir kıyım yaşandı. Müsteşrikler bile, bu dönemlerde Kur'an'ların ve kitapların yakıldığına özel vurgu yapmaktadırlar. ${ }^{60}$ Engizisyon kararlarıyla ya da Hiristiyan din adamlarının, kardinallerin emriyle yakılan kitapların haddi hesabı

55 Özdemir, Endülüs Müslümanları, (2013), s. 74, 157, 189; Garaudy, Endülüs'te İslâm, s. 249-250, 267; İsmail Durmuş, “İbn Hazm (Dil ve Edebiyat)” DİA, c. 20, İstanbul, 1999 , s. 58-61.

56 Nübâhî, Târihü Kudâti'l-Endelus, s. 202.

57 İbnü'l-Hatîb, A'mâlü'l-a'lâm, s. 319; Bkz. Parlak, Lisânüddîn, s. 21.

58 Reconquista (yeniden fetih/geri alma): Müslümanların Endülüs'ten atılarak Vizigot krallığının İspanya' da yeniden ihyasını hedefleyen uzun vadeli bir istila hareketidir. Özdemir, Endülüs Müslümanları, I, s. 153-155, Geniş bilgi için bkz. Lütfi Şeyban, Reconquista Endülüs'te Müslüman-Hıristiyan İlişkisi, İz Yayıncılık, İstanbul, 2010.

59 Şeyban, Reconquista s. 30.

60 Henry Charles Lea, İspanya Müslümanları Hıristiyanlaştırllmaları ve Sürülmeleri, İnkılâb, İstanbul, 2011, s. 98. 

yoktur. Bu bağlamda kardinal Ximenez (Jiménez)' in ${ }^{61}$ ismi ön plana çıkar. Lea'nın verdiği bilgiye göre; Ximenez, ${ }^{62}$ fakihlere çağrıda bulunarak ellerinde bulunan bütün kitapların teslim edilmesini istedi. Çoğu altın, gümüş ve paha biçilmez süslemelerle tezyin edilmiş beş bin kitap getirildi. Bu nadide eserlerin birçok talibi olmasına rağmen o, hepsini reddetti ve Alcala'daki kütüphanesi için ayırdığ 1 birkaç tıp kitabı hariç tamamının halkın huzurunda yakılmasını emretti. ${ }^{63}$

Lea'nin yukarıda yakılan kitaplarla ilgili olarak ifade ettiği beş bin rakamı, öyle anlaşılıyor ki her hangi bir günde ve bir seferde imha edilen kitap sayısını göstermektedir. Zira Kardinal Ximenez'in 1499'da Gırnata'da seksen bin Arapça kitabı yakarak imha ettirdiği bilinmektedir. ${ }^{64}$ Ximenez'i Gırnata başpiskoposluğuna getirerek bu kültürel kıyıma zemin hazırlayan Kral Ferdinand (1479-1516) fırsat buldukça benzer eylemleri gerçekleştirmiştir. ${ }^{65}$

İspanya'da Reconquista tamamlandıktan ve Gırnata işgal edildikten (1492) sonra, şehrin teslim anlaşmasıyla Müslümanlara her türlü teminat verilmiş olmasına rağmen, bu sözler tutulmamış, başta Müslümanlar olmak üzere Yahudilere de akıl almaz zulüm ve işkenceler yapılmıştır. ${ }^{66}$ Bunun üzerine varlıklarını gizlice devam ettirme gayretinde olan Moriskolar ${ }^{67}$, "Endülüs Mersiyeleri” diye isimlendirilen şiirlerle Müslüman devletlerden çeşitli dönemlerde

61 Ferdinand ile İzabella, Gırnata'yı ele geçirince (1492) burada bir başpiskoposluk tesis ederek başına da Hernando de Talavera'yı getirdi. Böylece hızlı bir Hıristiyanlaştırma gerçekleşeceği umuldu. Ancak kral ve kraliçe sürecin, arzu ettikleri hızda ilerlemediğini görünce Başpiskopos Talavera'nın yardımcılığına, 1499 yılının Temmuz ayında Tuleytula Başpiskoposu Fransisco Ximenez de Cisneros'u getirdiler. Müsteşrik Lea'nın ifadeleriyle "Ximenez, taşkın küstah, bağnaz, mütehakkim, katı ve de affetmez" bir yapıya sahipti. Lea, İspanya Müslümanları, s. 37, 40-41, 357, 358.

62 Özdemir, Endülüs Müslümanları, (2013), 160, 348; Şeyban, Reconquista, s. 30, 36; Lea, Isspanya Müslümanları, 42, 97, 98, 213; Garaudy, Endülüs'te İslâm, s. 267-268; Mesut Doğan, Endülüs, İz Yayınları, İstanbul, 2014, s. 122.

63 Lea İspanya Müslümanları, s. 42.

64 Şeyban, Reconquista, s. 36.

65 Ziya Paşa, Endülüs Tarihi, (sad.: Yasemin Çiçek), Timaş Yay., İstanbul, 2012, s. 266, 268.

66 Makkarî, Nefhu't-tîb min gusni'l-Endelüsi'r-ratîb ve zikru vezîrihâ Lisâniddin İbni'lHatîb, I-X, (nşr.: Yusuf eş-Şeyh M. el-Bukâî), Beyrut 1419/1998, V, s. 409.

67 Morisko, XVI. Asrın başında İspanya ve Portekiz'de zorla din değiştiren Mağribîlere verilen isimdir. Lea, İspanya Müslümanları, s. 55. 
yardım talep etmişlerdir. ${ }^{68}$ Devrin sultanlarına gönderilen bu mersiyelerde, onları etkilemek ve harekete geçirmek için Müslümanların çektikleri sıkıntılar ayrıntılı olarak tasvir edilmiştir. Bu şiirlerde kimi zaman camilerin kiliseye dönüştürülüp hilâlin yerine haçların asıldığı, ezanın yerini çan seslerinin aldığı vurgulanmış, kimi zaman da katliamlara özellikle de Müslüman kadınların, kızların uğradıkları tecavüzlere dikkat çekilmiştir. ${ }^{69}$ XVI. asrın hemen başında Sultan II. Bâyezid'e Endülüs'ten ikinci defa gelen elçinin okuduğu şiirde yukarıdakilerin yanı sıra Kur'an-ı Kerim'lerin ve kitapların yakıldığına özel olarak yer verilmiştir.

Verdikleri sözden döndüler ve bizi zorla Hiristiyanlaştırdılar Kur'an-ı Kerimleri yaktılar, çöpe ve pisliğe karıştırdılar Dinimizle ilgili bütün kitapları alaycılıkla ve hakaretle ateşe attılar Müslümanlara, okuyup avunacak bir kitap, bir Mushaf bile bırakmadılar. ${ }^{70}$

İspanyol dinî ve idarî otoriteleri tarafından, Müslümanların, din değiştirmelerinin önünde önemli bir engel olarak görülen kitaplar, toplatılarak meydanlarda halkın gözü önünde yakılmıştır. Başta Kur'an-1 Kerîm olmak üzere, ele geçirilen Arapça yazılmış ilmî ve kültürel içerikli kitapların hemen hemen hepsi imha edilmiştir ${ }^{71}$

Bunun böyle olduğu daha sonraki dönemlerde alınan radikal kararlarla net bir şekilde ortaya çıkmıştır. 1527 yılında bastırılan bir

68 Endülüslüler değişik zamanlarda Kuzey Afrika'daki Müslüman devletlerden Mısır'dan ve Osmanlı'dan yardım istemişlerdir. Bu konuda geniş bilgi için bkz: Meçhul müellif, Ahbâru'l-asr fi'n-kıdâi devlet-i Benî Nasr, (nşr.: Hüseyin Mu'nis), Kahire, 1991, s. 66 (Muhakkıkın Girişi); Makkarî, Nefhu't-tîb, V, s. 405, 406, 407; M. Abdullah İnan, Nihâyetü'l-Endelüs ve târîhu'l-Arabi'l-mutanassirîn, Mektebetü'l-Hancî, Kahire, 1987, s. 230-232; Mehmet Özdemir, “Osmanlı Endülüs Müslümanlarına Yardım Etmedi mi?” İslâmî Araştırmalar Dergisi, 1999, XII/ 3-4, s. 283-296.

69 Mehmed Nizameddin, "Endülüs Mersiyesi ve Endülüs Tarihine Kısa Bir Bakış" (haz.: M. Zekâi Konrapa), IYİED, II, İstanbul, 1964, s. 165-184.

70 Lütfi Şeyban, Mudejares Sefarades Endülüslü Müslüman ve Yahudilerin Osmanli'ya Göçleri, İz Yayıncilık, İstanbul, 2010, 240-241; Doğan, s. 122.

71 Özdemir, Endülüs Müslümanları, (2013), 348. Kitaplar, bir dinin, mezhebin ya da ekolün müntesiplerinin kendi görüşlerine bağlllıklarında çok önemli bir yere sahip olduğu inkâr edilemez bir gerçektir. Günümüzden yaklaşık 2600 yıl önce Filistin'i işgal eden Irak hükümdarı Nebukadnezzar, İsrailoğullarının kutsal metinlerini yakarak imha ederken amacı, onların dinini yok etmekti. Hamidullah, İslâm'ın Doğuşu, s. 17. 
Morisko isyanından sonra yapılan uygulamalar oldukça dikkat çekicidir. Teslim olan Moriskoların liderleri tutuklanıp tamamının silahları alınırken ellerinde bulunan bütün kitaplar yakılmıştır. ${ }^{72}$

Müslümanların İspanya'daki hâkimiyetlerini kaybetmelerinin (1492) üzerinden yetmiş beş yıl geçtiği hâlde bütün baskı ve işkencelere rağmen İspanya'da Müslüman varlığı silinememişti. Bu yüzden 1 Ocak 1567'de yürürlüğe konulmak üzere bir kanun yayınlanmış, bununla Moriskolara, üç yıl içerisinde Kastilya dilini öğrenme zorunluluğu getirilmişti. Bundan böyle alenen ya da gizlice Arapça konuşulması, yazılması ve bu dille mukaveleler yapılması kesinlikle yasaklanmıştı. Kanunun yürürlüğe girmesinden sonraki otuz gün içinde bütün Arapça kitapların, Gırnata Şehir Meclisi başkanı Pedro de Deza'ya teslim edilmesi istenmişti. Güya içinde suç unsuru bulunanlar yakılacak diğerleri sahiplerine geri verilecekti. Ancak ilginçtir, sahiplerine iade edilen kitaplar da üç yıl sonra tamamen imha edilmek şartıyla geri verilmişti.73

Başka şehirlerde de benzer şekilde kitap yakma işlemleri tekrarlandı. Kültürel tahribat ve kitap imhası o kadar büyük boyutlara ulaşmıştı ki İspanya Kralı II. Filip (1556-1598), Endülüslülerden kalma yazma eserleri toplamak istediğinde sadece iki bin beş yüz kitap bulabilmişti. ${ }^{74}$

Endülüs'te Müslümanlar arasında yaşanan kutuplaşmalar iki açıdan kültürel hayata darbe vurmuştur. Birincisi, böylesi ortamlarda eğitim-öğretim faaliyetleri sağlıklı yürütülememiş, ulema ve ilim meclisleri düzenli faaliyet yapamamış, eser telif etme, bunları başkalarıyla paylaşma, fikrî münazaralar yapma imkânları oldukça kısıtlanmıştır. İkinci olarak o zamana kadar elde edilmiş birikimler, müdevvenat, kütüphaneler çeşitli şekillerde zarar görmüş ve tahrip edilmiştir. Hatta birbirine muhalif olanlar, mücadelelerini, meydanlarda kitaplar yakacak boyutlara taşımışlardır. Örnek olarak Kurtuba isyanı (1009-1031) sirasında Kurtuba kütüphanelerinde yaşananları vermek mümkündür. Halife el-Hakem el-Mustansır'ın

\footnotetext{
72 Lea, Íspanya Müslümanlarl, s. 97.

73 Lea, İspanya Müslümanları, s. 212-213.

74 Özdemir, Endülüs Müslümanları, (2013), 160: Ayrıca bkz. Nebil Abdülhayy Rıdvan,, Cuhûdu'l-Osmâniyyîn li-İngâzi'l-Endelüs ve'stirdâdihi fî Matla'i'l-'Asri'l-Hadîs, Mektebetü't-Tâlibi'l-Câmiî, Mekke, 1408/1988, s. 48.
} 
kurduğu ve 400.000 cilt kitabı bulunan meşhur kütüphane, bahsi geçen isyan sırasında büyük zarar görmüştür. Kitapların bir kısmı yok pahasına satılırken bir kısmı da özellikle Berberîler'in şehre hâkim olmalarının akabinde talan edilmiştir. ${ }^{75}$ Aynı boyutlarda olmasa da benzer durumlar Gırnâta isyanları ya da darbeleri sırasında da yaşanmıştır. ${ }^{76}$

Kutuplaşmalar sonucunda meydana gelen isyan ve darbe ortamları "kitap hırsızları" için de bulunmaz fırsatlar sunmuştur. Avrupalılar, göz kamaştıran Endülüs kültür ve medeniyetine ilgi duymaya başladıklarında buradaki birikimi çeşitli yollardan aktarma faaliyetine girişmişlerdi. Konumuz açısından en dikkat çekici husus, kitaplarla ilgili olandır. Zira Avrupalılar, sahip olmak istedikleri kitapları, tüccarlar aracılığıyla Endülüs'ten normal yollardan edinebiliyorlardı. Ancak bir süre sonra gayr-i meşru yollara tevessül edilmeye başlandı. Bunun bir sonucu olarak Avrupa'da kitap hırsızlığını meslek hâline getirmiş yeni bir tüccar tipi ortaya çıktı. Bunlar Endülüs'ten çaldıkları kitapları birkaç yüz yıl boyunca Avrupa'nın büyük kentlerinin belli başlı merkezlerinde sattılar. Böylelikle İslâm dünyasının Endülüs'teki bilimsel ve kültürel birikimi, bilinenlerin dışında bambaşka bir yolla Avrupa'ya taşınmaya başladı. ${ }^{77}$ Müslümanlar arasında yaşanan çatışmaların böyle bir olaya zemin hazırladığı gerçeği de dikkatlerden kaçmamalıdır.

\section{Sonuç}

Mahiyet itibariyle aklın, algılama ve davranış geliştirme eyleminden kaynaklanan kutuplaşma ve tefrika, aslında bir adalet sorunudur. Kutuplaşmanın tarafları, yaptıkları değerlendirme hatası sonucunda tefrikaya düşmektedirler. Tefrika da insanlara hak ettikleri şeyi vermeme sonucunu doğurmaktadır. Kur'an'da'da adalete özel vurgu yapılması, onun zıddı olan kutuplaşmanın tamamen

75 Özellikle Kurtuba isyanının kültürel sonuçları için bkz. Abdülvehhâb Halil edDebbâğ, "Eserü'l-fitne fi'l-hareketi'l-ilmiyye fî Kurtuba", Âfâku's-sekâfe ve't-türâs, 1420/1999, VII, s. 25-26, 103-111. Kurtuba isyanının İbn Hazm üzerindeki etkileri ve Tavku'l-hamâme' deki izleri için bkz. Abdurrahman Abdurraûf el-Hancî, “Eserü fitneti Kurtuba ale'l-mürtekezâti'n-nefsiyye ve'l-ahlâkıyye li'bni Hazmi'l-Endelüsiyyi fî kitâbihi Tavku'l-Hamâme", es-Sicillü'l-ilmî li-nedveti'l-Endelüs I-V, nşr. Abdullah b. Ali ez-Zeydân ve dğr., I, Mektebetü'l-Meliki'l-Abdilazizi'lâmme, Riyad, 1996, s. 133-157.

76 Bkz. İbnü'l-Hatîb, A'mâl, s. 319.

77 Geniş bilgi için kz. Parlak, Endülüs'ün Çökü̧̧ü, s. 221-222; Yusuf Kaplan, "Osmanlılarda Matbaa: Bir Medeniyet Krizi Sorunu", Osmanl, VII, 232-233. 
karşısında yer almayı gerekli kılmaktadır. Bu karşı duruştan, maksadın hâsıl olabilmesi için öncelikle kutuplaşmanın nasıl tezahür ettiği, sebeplerinin neler olduğu ve ne tür tahribata yol açtığı bilinmelidir.

Bu hususlarla ilgili olarak ulaştığımız sonuçları şöylece özetleyebiliriz: Kutuplaşmalar, toplumda bireysel menfaat çatışmaları ve mezhep, tarikat çatışmaları şeklinde tezahür eder ve çeşitli sebeplerle tırmandırılarak kronik bir mahiyete büründürülür. Bu sebeplerin başında da "Hedef yoksunluğu, siyasî ihtiraslar, çıkar çatışmaları, dış güçlerin tahrik ve teşvikleri," yer almaktadır.

Bir toplum, tefrikanın en somut şekli olan kutuplaşma hastalığına müptela olduğunda çeşitli sorunları yaşamaya mahkûm olur. İslâm tarihinin değişik dönemlerinde farklı coğrafyalarda yaşanan bu sıkıntılar, ayniyla Endülüs'te de söz konusu olmuş ve İberya Yarımadası'ndaki Müslümanlar, içine düştükleri kutuplaşma sonucunda siyasal, sosyal, kültürel ve ekonomik problemlere maruz kalmışlardır.

Bu çalışmada sadece kültürel problemler ele alınmıştır. Anlaşılan o ki Endülüs'ün siyasî tarihinde meydana gelen olaylara kilitlenmenin bir sonucu olarak bu toplumun yaşadığı kültürel tahribat yeterince algılanamamış, diğer bir deyişle o coğrafyada yaşanan kültürel yıkım, siyasî olayların gölgesinde kalmıştır.

Endülüs'teki kutuplaşmanın sonucunda biri Müslümanlardan, diğeri dış güçlerden kaynaklanan büyük bir kültürel tahribat meydana gelmiştir. Yukarıda zikri geçen sebeplerle Müslümanlar birbirleriyle mücadele etmiş, bu esnada ulema ve talebe ciddi sorunlar yaşamış, hayatını kaybedenler, hapsedilen ve sürgüne gönderilenler olmuştur. İlim meclisleri düzenli ve verimli faaliyet gösterememiş, eser teliflerinde sorunlar yaşanmış, büyük emeklerle kaleme alınan eserler, yakılarak imha edilmiştir. Hıristiyan işgalleri bu tahrifatı doruk noktasına ulaştırmış, Endülüs'ün yüz binlerce kitaptan oluşan kütüphaneleri yakılmış, yıkılmıştır.

Benzer hususların günümüzde de yaşanmaması için kutuplaşmanın mahiyetinin, sebep ve sonuçlarının iyi kavranması, Kur'an'ın kutuplaşma konusundaki tespitlerinin doğru anlaşılması, konuyla ilgili olarak Hz. Peygamber'in tavrının tespit edilip örnek alınması, Kur'an ve Hz. Peygamber dişında kalan bütün alt aidiyetlerin bu iki 
temel ölçünün önüne geçirilmemesi, üstüne çıkarılmaması gerçeğinin iyi anlaşılması, bu sorunu yaşayan toplumların bütün unsurlarının ortak hareket edebilme becerilerini geliştirmesi, İslâm dünyasında ve Anadolu'da bir arada yaşama tecrübesinin yeniden hayata geçirilmesi gerekmektedir.

\section{Kaynakça}

Abdülaziz Atîk, el-Edebü'l Arabîfi'l-Endelüs, Beyrut 1976.

Abdurrahman Abdurraûf Hancî, “Eserü fitneti Kurtuba ale'l-mürtekezâti'n-nefsiyye ve'l-ahlâkıyye li'bni Hazmi'l-Endelüsiyyi fî kitâbihi Tavku'l-Hamâme", es-Sicillü'l-ilmî li-nedveti'l-Endelüs, I-V, nşr. Abdullah b. Ali ez- Zeydân ve dğr., I, Mektebetü'l-Meliki'l-Abdilazizi'lâmme, Riyad, 1996, 133-157.

Abdülkerim Özaydın, "Âmirîler" DİA, c. 3, İstanbul, 1991.

Abdülmelik İbn Sâhibis-Salât, (ö. 594/1198'den sonra), el-Menn bi'l-imâme (Târîhü bilâdi'l-Mă̆ribi ve'l-Endelüs fì ahdi'l-Muvahhidîn, tahk.:Abdülhâdî et-Tâzâ), Beyrut 1987.

Afşar Timuçin, "Ayrımcılık”, Ayrımcılık, XXIX, Felsefelogos Yay., İstanbul, Nisan 2006/I.

Ahmed b. Yahya b. Ahmed ed- Dabbî el-Endelüsî, (ö. 599/1202), Buğyetü'lmültemis fî târîhi ricâli ehli'l-Endelüs, Dârül-Kitâbi'l-Arabî, Kahire, 1967.

Ahmed er-Reysûnî,- Ali Hakan Çavuşoğlu, "Şâtıbî, İbrahim b. Mûsâ", DİA, c. 38, İstanbul, 2010.

Ahmet Baltac1, “İbnü'l-Arabî”, DİA, c. 20, İstanbul, 1999.

Alex Demiroviç, “Us ve Dışlanmanın Mantığı”, (çev.: Metin Toprak), Ayrımcılık, XXIX, Felsefelogos Yay., İstanbul, Nisan 2006/I.

Ata Devrim, "Türcülügün Felsefî ve Psikanalist Dayanakları" Ayrımcılık, XXIX, Felsefelogos Yay., İstanbul, Nisan 2006/I.

Bekir Karlığa “İbn Rüşd” DİA, c. 20, İstanbul, 1999.

Ömer Bozkurt “13. Yüzyıl İslam Düşüncesinde İbn Rüşd'e Olan İlgisizliğin Sebep ve Sonuçları Üzerine" Uluslar arası 13. Yüzyılda Felsefe Sempozyumu, Ankara, 16-17 Kasım 2013. (Uluslararası 13. Yüzyılda Felsefe Sempozyumu Bildirileri, ed. M. Demirkol, E. Kala, YBU Yayınları, Ankara, 2014.

Cengiz Kallek, “İbn Zerb” DİA, c. 20, İstanbul, 1999.

Ebü'l-Hasan en-Nübâhî (ö. 792/1390), Târihü kudâti'l-Endelusî, (el-Markabetu'l-ulyâ, tah. Lecnetü İhyâit-Türâsi'l-Arabi), Beyrut 1403/1983.

Erkan Tüzün, “Nietzsche'de ve Heiddegger'de Ayrımcılığın Onaylanması", Ayrımcılık, XXIX, Felsefelogos Yay., İstanbul, Nisan 2006/I.

Frieder Otto Wolf, "Ayrımcılık”, (çev.: Fehmi Ünsalan), Ayrımcılık, XXIX, Felsefelogos Yay., İstanbul, Nisan 2006/I.

H. Yunus Apaydın, “İbn Hazm”, DİA, c. 20, İstanbul, 1999. 
Enđülüs'te Toplumsal Kutuplaşmanın Sebepleri ve Kültürel Sonuçları

Harun Tepe, "Etik Bir Sorun Olarak Ayrımcılık”, Ayrımcılık, XXIX, Felsefelogos Yay., İstanbul, Nisan 2006/I.

Henry Charles Lea, İspanya Müslümanları Hıristiyanlaştırılmaları ve Sürülmeleri, İnk1lâb, İstanbul, 2011.

İbnü'l-Hatîb, A'mâlü'l-a'lâm fîmen buyi'a kable'l-ihtilâm min mulûki İslâm, (tahk.: Levi Provençal, E.), Beyrut 1956.

Târihü'l-Mağribi'l-arabî fì asri'l-vesît, Dârü'l-Beyzâ 1964.

İsmail Durmuş, “İbn Hazm (Dil ve Edebiyat)” DİA, c. 20, İstanbul, 1999.

İsmail Yiğit, "Murâbitlar" DİA, c. 31, İstanbul, 2006.

Lütfi Şeyban, Mudejares Sefarades Endülüslü Müslüman ve Yahudilerin Osmanlı'ya Göçleri, İz Yayıncılık, İstanbul, 2010.

, Reconquista Endülüs'te Müslüman-Hıristiyan İlişkisi, İz Yayıncılık, İstanbul, 2010.

M. Abdullah İnan, Nihâyetü'l-Endelüs ve târîhu'l-Arabi'l-mutanassırîn, Mektebetü'l-Hancî, Kahire, 1987.

Makkarî, Nefhu't-tîb min gusni'l-Endelüsi'r-ratîb ve zikru vezîrihâ Lisâniddin İbni'l-Hatîb, I-X, (nşr.: Yusuf eş-Şeyh M. el-Bukâî), Beyrut 1419/1998.

Meçhul müellif, Ahbâru'l-asr fi'n-kıdâi devlet-i Ben̂̂ Nasr, (nşr.: Hüseyin Mu'nis), Kahire, 1991.

Mehmed Nizameddin, “Endülüs Mersiyesi ve Endülüs Tarihine Kısa Bir Bakış" (haz.: M. Zekâi Konrapa), IYYIED, II, İstanbul, 1964.

Mehmet Özdemir, "IX. Yüzyıl Endülüs'ünde Zındıklık Suçlamaları”, Ankara Üniversitesi İlahiyat Fakültesi Dergisi, 38. , Endülüs Müslümanları, I, Türkiye Diyanet Vakfı, Ankara, 1994. , "Hammûdîler", DİA, c. 15, İstanbul, 1997.

, “Osmanlı Endülüs Müslümanlarına Yardım Etmedi mi?" İslâmî Araştırmalar Dergisi, 1999, XII/ 3-4.

"Muvahhidler" DIA, c. 31, İstanbul, 2006.

, "İbn Rüşd'ün Yaşadığı Asırda Endülüs", Diyanet İlmî Dergi, c. 48, say1: 3, Ankara, 2012.

, Endülüs Müslümanları Kültür ve Medeniyet, Türkiye Diyanet Vakfı, Ankara, 2013.

Mesut Doğan, Endülüs, İz Yayıncılık, İstanbul, 2014.

Muhammed Hamidullah, İslâm'ın Doğuşu, (çev.: Murat Çiftkaya), Beyan Yayınları, İstanbul, 2010.

Mustafa Aydın, “İbn Şüheyd”, DİA, c. 20, İstanbul, 1999.

Mustafa Çağrıcı, “İbn Meserre”, DİA, c. 20, İstanbul, 1999.

Nihat Azamat, “İbnü'l-Arif”, DİA, c. 20, İstanbul, 1999.

Nizamettin Parlak, Lisânüddîn İbnü'l-Hatîb'in Siyasî Kişiliği ve Tarihçiliği, Türk Tarih Kurumu, Ankara, 2012.

, Endülüs'ün Çöküşü: Benî Ahmer'de Darbeler ve İsyanlar, Hikmetevi Yayınları, İstanbul, 2014. 
Ömer Mahir Alper, “İbnü'l-Gurbâlî”, DİA, c. 21, İstanbul, 2000.

Ömer Nasuhi Bilmen, Hukukı İslâmiyye ve Islahatı Fıkhiyye Kamusu, I-VIII, Bilmen Yayınevi, İstanbul, ts.

Rahmi Er, “İbn Zeydûn”, DIA, c. 20, İstanbul, 1999. “İbn Vehbûn", DİA, c. 20, İstanbul, 1999.

Roger Garaudy, Endülüs'te İslâm, (çev.: Cemal Aydın), Türk Edebiyatı Vakfı Yayınları, İstanbul, 2014.

Süha Abbûd Accâr, “İbn Zekvân”, DİA, c. 20, İstanbul, 1999.

Thomas B. Irving, "İbnü'l-Faradi”, DİA, c. 21, İstanbul, 2000.

Vahap Özpolat, Demokratik Vatandaşlık Birlikte Yaşama Kültürü, Hegem Yayınları, Ankara, 2009.

W. Montgomery Watt-Cachia, Pierre, Endülüs Tarihi, (çev.: Cumhur Esin Adıgüzel, Qiyas Şükürov), Küre Yay., İstanbul, 2011.

Yaşar Aydınlı, "İbn Bâcce”, DİA, c. 19, İstanbul, 1999.

Zerrin Kurtoğlu, “Dünyada Özcü Olmayan Tarzlarda Katılma İmkânı”, Ayrımcillk, XXIX, Felsefelogos Yay., İstanbul, Nisan 2006/I.

Ziya Paşa, Endülüs Tarihi, (sad.: Yasemin Çiçek), Timaş Yay., İstanbul, 2012. Zülfikar Tüccar, “İbn Side”, DİA, c. 20, İstanbul, 1999. 


\section{Mílel VE NiHAL}

inanç, kültür ve mitoloji araştırmaları dergisi

Cilt/Volume: 12 Sayı/Number: 1 Ocak - Haziran / January - June 2015

ISSN: 1304-5482

Bu dergi uluslararası EBSCO HOST Research Databases veri indeksi ve

TÜBİTAK-ULAKBİM Sosyal ve Beşeri Bilimler Veri Tabanı tarafından taranmaktadır.

\section{Sahibi / Owner}

Milel ve Nihal Eğitim, Kültür ve Düşünce Platformu Derneği adına Şinasi Gündüz

$$
\begin{gathered}
\text { Yazı İşleri Sorumlusu / Legal Representative } \\
\text { Yasin Aktay }
\end{gathered}
$$

Editör / Editor

Şinasi Gündüz

Editör Yrd. / Co-Editor

Cengiz Batuk

Hakan Olgun

\section{Sayı Editörü / Editor of Issue}

Feridun Bilgin

Yayın Kurulu/ Editorial Board*

Alpaslan Açıkgenç, Ayaz Akkoyun, Yasin Aktay, Mahmut Aydın,

Cengiz Batuk, Şinasi Gündüz, İbrahim Kayan, Hakan Olgun, Necdet Subaşı, Burhanettin Tatar

\section{Danışma Kurulu/Advisory Board*}

Baki Adam (Prof. Dr., AÜ); Mohd. Mumtaz Ali (Prof. International Islamic U. Malezya); Adnan Aslan (Prof.Dr., Süleyman Şah Ü.); Kemal Ataman (Doç.Dr., Uludağ Ü.); Mehmet Akif Aydın (Prof. Dr., Marmara Ü.); Yılmaz Can (Prof. Dr., OMÜ); Ahmet Çakır (Doç. Dr., OMÜ); Mehmet Çelik

(Prof. Dr., Celal Bayar Ü.); Waleck S. Dalpour (Prof. University of Maine at Farmington); İsmail

Engin (Dr., Berlin); Cemalettin Erdemci (Prof.Dr. YYÜ); Tahsin Görgün (Prof.Dr., 29

Mayıs Ü.) Ahmet Güç (Prof.Dr., Uludağ Ü.); Recep Gün (Doç. Dr., OMÜ); Ö. Faruk Harman

(Prof.Dr., Mar.Ü.); Erica C.D. Hunter (Dr., Cambridge U.); Mehmet Katar (Prof. Dr., A.Ü.);

Mahmut Kaya (Prof. Dr., İ.Ü.); Sadık Kılıç (Prof.Dr., Atatürk Ü..); Şevket Kotan (Y.Doç.Dr., İ.Ü.);

İlhan Kutluer (Prof.Dr., Mar. Ü.); George F. McLean (Prof. Catholic Univ., Washington DC); Ahmet Yaşar Ocak (Prof. Dr., Hacettepe Ü.); Jon Oplinger (Prof. University of Maine at Farmington); Ömer

Özsoy (Prof.Dr., Frankfurt U.); Roselie Helena de Souza Pereira (Mestre em

Filofia-USP; UNICAMP Brasil); Ekrem Sarıkçığlu (Prof.Dr., SDÜ); Hüseyin Sarıoğlu (Prof.Dr.,

IÜ); Bobby S. Sayyid (Dr. Leeds U.); Mustafa Sinanoğlu (Prof.Dr., 29 Mayıs Ü.); Mahfuz Söylemez

(Prof.Dr. İÜ); Necdet Subaşı (Y.Doç.Dr., DİB); Bülent Şenay (Prof.Dr., UÜ); İsmail Taşpınar

(Prof.Dr. Mar.Ü.); C. Sadık Yaran (Prof.Dr., OMÜ); Ali Murat Yel (Prof.Dr., Fatih Ü.); Hüseyin Yılmaz (Doç.Dr., YYÜ); Ali İhsan Yitik (Prof. Dr., DEÜ)

$$
\text { * Soyadına göre alfabetik sıra / In alphabetical order }
$$

\section{Kapak ve Sayfa Tasarımı / Cover \& Page Design} İnan $\mathrm{Avc1}$

\section{Baskı / Publication}

Ladin Ofset - İstanbul, Ekim 2015

2.Mat. Sit. 3 NB 15 Topkapi İstanbul / İsmail Tüz 02125012418

Yönetim Yeri / Administration Place

Milel ve Nihal Eğitim, Kültür ve Düşünce Platformu Derneği

Fevzipaşa Cad. Şehit Mehmet Sarper Alus Sok. No: 5, K.: 3, Tel: (0212) 5339731 Fatih/İstanbul www.milelvenihal.org e-posta: dergi@milelvenihal.org

Milel ve Nihal yılda iki sayı olarak altı ayda bir yayımlanan uluslararası hakemli bir dergidir.

Milel ve Nihal' de yayımlanan yazıların bilimsel ve hukuki sorumluluğu yazarlarına aittir. Yayım dili Türkçe ve İngilizce' dir. Yayımlanan yazıların bütün yayın hakları Milel ve Nihal'e ait olup, yayıncının izni olmadan kısmen veya tamamen basılamaz, çoğaltılamaz ve elektronik ortama taşınamaz. Yazıların yayımlanıp yayımlanmamasından yayın kurulu sorumludur. 


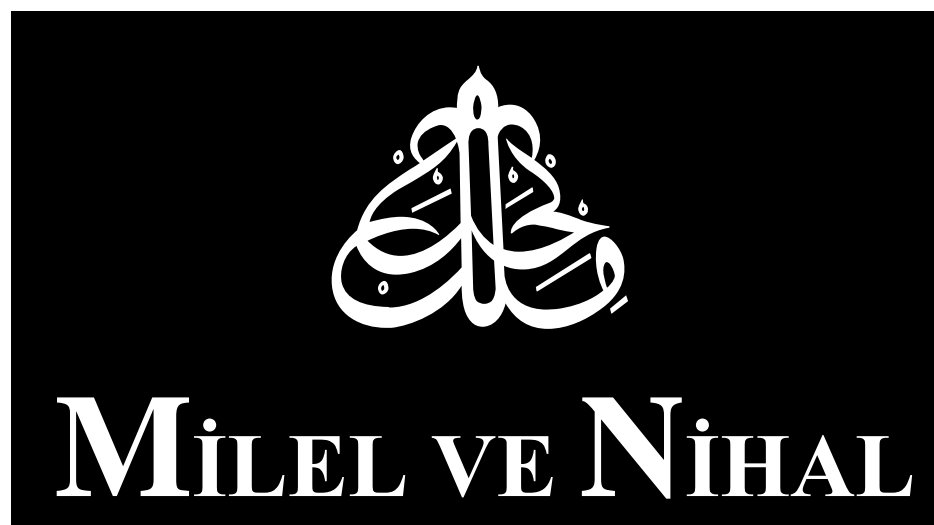

inanç, kültür ve mitoloji araştırmaları derogisi

ISSN: 1304-5482

ENDÜLÜS

Cilt/Volume: 12 Sayı/Number: 1

Ocak - Haziran / J anuary - June 2015 
